\title{
THE EFFECT OF ANGER MANAGEMENT TRAINING TOWARD AGGRESSIVE BEHAVIOR IN ADOLESCENTS
}

\author{
Ellyana D. Farisandy, Nurul Hartini \\ Faculty of Psychology, Airlangga University \\ J1. Airlangga No.4-6, Universitas Airlangga, Surabaya, Indonesia 60115 \\ ellyanadwif@email.com
}

\begin{abstract}
The purpose of this study is to examine the effect of anger management training on adolescent aggressive behavior. This study uses a quasi-experimental method, with one group pretest-posttest design. The treatment is only given to one group. The population of this study are 15 male neglected and street adolescences. The subjects of this study were six male adolescences $\left(\mathrm{M}_{\mathrm{age}}=14\right.$ years old, $\left.\mathrm{SD}=.75\right)$, with highly aggressive behavior. Aggression behavior is measured using the CBCL (Child Behavior Checklist). The adolescence who have scores above the threshold line are then involved in this study. Data were collected before and after the intervention using the Aggression Questionnaire (AQ) (29 items, $\alpha=.917)$. As a treatment, a nine-session of anger management training was conducted. The data were analyzed with the wilcoxon signed-rank test, and the result shows that there is a significant difference knowledge $(p=.028, p<.05)$ and aggressive behavior $(p=.028, p$ $<.05)$ before and after training. It can be concluded that anger management training can be considered as a good program in increasing knowledge about aggression and procedure in reducing aggressive behavior.
\end{abstract}

Keywords: aggression; anger; anger management; adolescence

\begin{abstract}
Abstrak
Tujuan dari penelitian ini adalah untuk menguji pengaruh anger management training terhadap perilaku agresi remaja. Penelitian ini menggunakan metode eksperimen quasi yakni one group pretest-posttest dimana hanya terdapat satu kelompok yang akan diberikan intervensi. Populasi penelitian ini adalah 15 remaja laki-laki yang terdiri dari anak terlantar dan juga anak jalanan. Partisipan penelitian merupakan enam remaja laki-laki $\left(M_{u s i a}=\right.$ 14 tahun, $S D=0,75$ ) yang memiliki perilaku agresi berada di atas garis ambang berdasar alat ukur CBCL (Child Behavior Checklist). Pengumpulan data sebelum dan sesudah intervensi menggunakan Agression Questionnare (AQ) (29 jumlah item, $\alpha=0$,917). Intervensi yang diberikan adalah sembilan sesi anger management training. Berdasar hasil analisis data yang diuji melalui wilcoxon signed rank test, diketahui bahwa terdapat perbedaan yang signifikan antara pengetahuan partisipan penelitian mengenai agresi $(p=0,028, \mathrm{p}<0,05)$ dan perilaku agresi $(p=0,028, \mathrm{p}<0,05)$ sebelum dan setelah dilakukannya intervensi. Hal ini dapat disimpulkan bahwa anger management training dapat dianggap sebagai program yang efektif dalam meningkatkan pengetahuan mengenai agresi serta menurunkan perilaku agresi.
\end{abstract}

Kata kunci: agresi; marah; manajemen kemarahan; remaja

\section{INTRODUCTION}

Anger is an emotion, most often felt by individuals (Bhave \& Saini, 2009; Williams, 2011). Anger emerge to respond to the threats, that threatening something consequential and special for individuals and can help individuals protect themselves from danger (Reis-Dennis, 2018). Anger is a consequence of various factors, internal and external factors, such as: biological, psychological, and social. The internal factors include personality types, lack of problem-solving skills, tension, anxiety, depression, and the presence of unpleasant experiences. The external factors are environmental factors (such as traffic jams, barking dogs, loud noises), peer and media 
influences, socioeconomic status, social pressures, and some others. The way an individual expresses their anger also vary. Spielberger (Bhave \& Saini, 2009) revealed that there are three ways to express anger, namely: (1) directed towards others (directed outward towards others with aggression), (2) directed inward leading to self-destructive behavior, and (3) controlled. When individuals do not know how to control their anger, one of the methods used by individuals to express their anger is, do the aggression (Wilkowski \& Robinson, 2009).

Recently there is much news about teenagers committing acts of aggression, both verbally and physically. Data from the Indonesian Commission for Child Protection (KPAI) reveals 140 reported cases of Children Facing Law (ABH) in 2018 because of physical and psychological violence behavior (Sulaiman, 2019). The Minister of Women's Empowerment and Child Protection, Yohana Yembise, announced the result's survey of the National Life and Child Life Experience (SNPHAR) in 2018. The result showed that the majority of violence cases in adolescents aged $13-24$ years were carried out by peers (Rahayu, 2019). According to Eltink et al. (2017) and Hsiesh $\&$ Chen (2017), aggression is a physical and verbal behavior intended to hurt someone (Eltink, Hoove, De Jongh, Helm, Wissink, \& Stams, 2017; Hsiesh \& Chen, 2017). The behaviors include kicking, slapping, threatening, insulting, and gossiping others. Besides, aggressive behaviors also include destroying pieces of stuff, lying, and other behaviors that aim to hurt others. Buss (Pechorro, Barroso, Poiares, Oliveira, \& Torrealday, 2015) explains another definition of aggression. Buss defines aggression as a response that harms other organisms. Bushman and Anderson (Potirniche \& Enache, 2014) define aggression as deliberate behavior to produce particular destruction, either by hurting, destroying, or causing material damage. Based on the above definition, it can be concluded that aggressive behavior is violent behavior, both verbally and physically, intended to damage or injure the individual/object.

There are several aspects of aggressive behavior, such as physical aggression, verbal aggression, anger, and hostility. (a) Physical aggression refers to a form of behavior, which demonstrates physical attack and aims to hurt someone by hitting, kicking, pushing, and throwing things. (b) Verbal aggression is interpreted as aggressive behavior by addressing hurtful words, such as arguing, shouting, threatening, cursing, insinuating, slandering, and sarcasm. Anger is associated with a sense of control. (c) Anger is a category of indirect aggression, such feelings of hatred to others or anything because someone cannot achieve a goal. (d) Hostility is a cognitive component related to feelings of resentment, distrust, cynicism, gossip, hatred, vindication, jealousy, suspicion, injustice, and alienation (Buss \& Perry, 1992; Reyna, Lello, Sanchez, \& Brussino, 2011).

An individual often uses aggressive behavior in order to solve the problem instantly. Aggression emerges because of uncontrolled angry emotion, that actually hurt the perpetrators and also harms others (Nasir \& Ghani, 2014). Individuals who can manage their anger can control themselves in a stressful situation. These individuals also able to be more constructive in dealing with angry, unhappy, and upset feelings. Lozovska and Gudaite (2013) explain that aggression can be triggered by frustration about unmet physiological needs, security, belongingness, self-esteem, or selfconfidence. Bhave and Saini (2009) suggest that children with busy working parents will tend to develop aggressive behavior because they do not get enough attention and guidance from their parents on facing the problems in daily life. The alterations in family conditions, such as divorce, remarriage, children with a single parent, and working parents, also increase the child's risk of aggression. 
The family conditions mentioned above are related to the condition of foster adolescence in UPTD Kampung Anak Negeri, a social home for former neglected children, street children, and brat. Before being foster children in the UPTD Kampung Anak Negeri, the adolescence spent time on the streets as buskers and beggars (Kampung Anak Negeri, 2018). In their daily relationship with their peers, the aggression often emerges both, verbally and physically. Bhave and Saini (2009) revealed that peers usually replace the family as the center of teenagers' socializing. Peers interplay to engage in antisocial behavior, including aggression. Liu, Lewis, and Evans (2014) also announced that peers play an essential role in the aggressive behavior of adolescents. Usually, individuals demonstrate aggressive behavior, show power or control to gain popularity or elevate social status. Peer pressure can also cause aggressive behavior because adolescence is afraid of being isolated or losing social standing.

Based on family factors perspective, the authoritarian parenting style use violence to discipline the children, apply negative communication between parents and children, have often conflicts in the family, have lack of family support and lack of emotional ties between parents and children also place an individual risk in aggressive behavior (López, Pérez, Ochoa, \& Ruiz, 2008; Bhave \& Saini, 2009; Jiménez \& Estévez, 2017; Estévez, Jiménez, \& Moreno, 2018). Bhave and Saini (2009) further explained that children who are exposed to physical and verbal violence could also increase the risk of acting aggressively and children learn how to deal with their problems by imitating the behavior of their parents.

In UPTD Kampung Anak Negeri, where the participants recently live, four social workers are responsible for supervising approximately 35 childrens, and they also worked in shifts every day (Kampung Anak
Negeri, 2018). The support, service, and care do not run optimally because of a large number of the ratio between children or adolescence and the social worker. This ratio also leads to a lack of emotional closeness among children and the social worker (Sandri, 2015). This situation is in line with the argument of Bhave and Saini (2009). They explain that adolescence needs direction, assistance, and proper guidance from adults around them so that adolescence can protect themselves from the negative emotion and behavior that can cause anger and aggression. The social worker also implement an authoritarian parenting style and use punishment to discipline the children (Sandri, 2015). The parenting style leads foster children to develop aggression as a way to solve the problems.

In childhood, the foster children in UPTD Kampung Anak Negeri lacked proper preparation in facing their developmental tasks in adolescence, so they became unstable. Their childhood is filled with pressures that arise from different factors, such as economic, family, and friends. Glowacz, Veronneau, and Born (2013) discovered that individuals coming from low socioeconomic status are more at risk to behave aggressively than those coming from high socioeconomic status. Furthermore, Jargowsky (Bhave \& Saini, 2009) proved that the inadequacy of leisure resources, financial deficits, as well as the unconducive home and social environment often makes individuals always feel angry. The situation in low economic status ultimately makes people engage in unhealthy behaviors such as aggression because they are unable to control their anger constructively.

The existence of aggression does not only trigger a negative impact on the victim but also on the perpetrator. Aggressive individuals exhibit psychosocial disabilities, a high risk of social rejection, low academic achievement, truant, involvement in misbehavior, substance abuse, and various mental health problems, include severe 
depression. Aggressive individuals are also more likely to experience psychiatric problems and criminal behavior (Houbre, Tarquinio, Thuillier, \& Hergott, 2006; Garcia-Sancho, Salguero, \& FernandezBerrocal, 2014; Estévez, Jiménez, Moreno, 2018; Poling, Smith, Smith Taylor, \& Worth, 2019). Other research also proved that aggression could lead to financial losses (fines given by the court), loss of freedom (imprisonment), and even loss of life (execution). After being released from prison, individuals tend to face losing jobs, divorce, and poverty, which can lead to being more aggressive in criminal actions to obtain resources (Liu, 2004; Liu, Lewis, \& Ivans, 2014). This research focuses on measuring the effect of anger management training on adolescence with aggressive behavior in UPTD Kampung Anak Negri. The foster children in the UPTD consist of former brat, neglected children, street children, who were often exposed to aggressive behavior from friends, parents, and neighborhoods. The majority of the adolescence in UPTD showed often physical and verbally aggressive behavior, and they are less able to control their anger. The training aims to give knowledge and skills in constructively controlling anger in their environment.

In this study, training about anger management were constructed to reduce aggressive behavior in adolescents. Based on several previous studies, anger management training is success to reduce aggressive behavior at all ages (Mohammadi, Kahnamouei, Allahvirdiyan, \& Habibzadeh, 2010; Valizadeh, Davaji, \& Nikamal, 2010; Shokoohi-Yekta, Parand, \& Zamani, 2010; Shokoohi- Yekta, Zamani, \& Ahmadi, 2011; Foumany \& Salehi, 2013; Mokhber, Masjedi, \& Bakhtiari, 2016; Lok, Bademli, \& Canbaz, 2018). However, there is still less evidence that anger management training also affects adolescence in Indonesia, especially adolescence who are living in social homes in Indonesia. In order to ease the knowledge transfer and prevent flatness, the training module was constructed with varies methods, such as lecture, discussions, role play, and also games. Besides, by observing and imitating the behavior, the participants can develop new skills, solve problems with more adaptive manner, and can exchange ideas, so that they can understand each other. The purpose of the research was to examine the effect of anger management training in reducing the aggressive behavior of adolescents as foster children in UPTD Kampung Anak Negeri. This study hypothesizes that there is an influence of anger management training on the knowledge and behavior of adolescent aggression in UPTD Kampung Anak Negeri.

\section{METHOD}

This study used a quasi-experimental method with just one group pretest-posttest design. Three measurement tools were used to measure the level of aggressive behavior, knowledge about aggressive behavior, and self-report about aggressive behavior. A questionnaire and self-report about aggressive behavior were twice administrated, namely before and after the intervention, as pretest and posttest. Pretest and posttest scores were compared to determine whether the training brings a positive transformation in aggression management knowledge and skill or not. The pretest and posttest scores were calculated using the non-parametric wilcoxon signed rank test. This non-parametric test was used because the number of participants is a small and unmet normal distribution of the data. Data were analyzed with SPSS 16.00.

\section{Participants}

This study used non-probability sampling techniques, namely a purposive sampling technique. Several criteria were determined to obtain the participants (Neuman, 2014). In this study, six adolescents aged $13-18$ years old were involved $\left(\mathrm{M}_{\mathrm{age}}=14\right.$ years, $\mathrm{SD}=$ .75). All the participants are living in the Social Home, UPTD Kampung Anak Negeri. UPTD Kampung Anak Negeri is a 
government institute that accommodates street children, neglected children, and brat under 18 years old. The institute concern about caring the children and adolescence so that they can function adequately in their future social life. Based on CBCL (Child Behavior Checklist), the six adolescents have high scores of aggression. The CBCL scale was filled up by the caretaker or academic advisor in the institution (Mean CBCL score=26). Based on preliminary data, adolescents living in UPTD Kampung Anak Negeri often commit aggression, both physically and verbally. These categories of aggression are conducted as a manifestation of anger, felt by the adolescent. The physical aggression usually performed by the participant are hitting, kicking, and throwing things at other people. The verbal aggression, which is issued by the participants is, raising the tone of voice, shouting, threatening, saying harsh and dirty words. All participants in this study had received permission from both the mentor and the academic supervisor at the UPTD Kampung Anak Negeri to be involved in all sessions of intervention.

\section{Measurement}

Measurement tools, used in this study are:

1. CBCL (Child Behavior Checklist)

In this study, CBCL was used as a screening tool. CBCL is a questionnaire that is given to parents or caregiver. CBCL assess the severity level of aggressive behavior in their child. CBCL is used for children aged 4-18 years. CBCL has a total of 12 items of behavior problems with a three-point Likert scale ( 0 = "absent", 2 = "occurs often"). Scores obtained from CBCL consist of total externalizing scores and total internalizing scores. The total score can be categorized into eight subscales, namely withdrawn, anxious/depressed, somatic complaint, thought problem, attention problem, social problem, aggressive behavior, and delinquent behavior. One example of items from aggressive behavior is item number 37, "often get into fights." CBCL has a test-retest reliability value ranging from .89-.90 and higher (Achenbach, 1991; Rishel, Greeno, Marcus, Shear \& Anderson, 2005).

2. Instrument to measure the knowledge about aggression

This instrument was used to measure the participants' knowledge about aggression and given as pretest and posttest. This instrument was constructed based on the module material, that would be delivered. This tool consisted of seven open questions, and the answer to each question would be rated with point ranges from 0 25 points. The total score that could be gained by participants ranged between 0 100. The reliability and validity of this tool were also measured. Based on the validity test, the $\mathrm{KMO}$ value of the measuring instrument was .500 (sig. Barlett $=.045)$. The result indicates that the measuring instruments used in this study was valid and met the requirements for further analysis. Based on the reliability test, this measuring instrument has a Cronbach alpha value of .904 (CITC range $=.577-.954)$. The result indicates that the measuring instrument used to measure participants' knowledge about aggression was reliable. The measuring instruments were given before and after the intervention using a paper-based test and conducted in the counseling room of the UPTD Kampung Anak Negeri.

\section{AQ (Agression Questionnaire)}

The Aggression Questionnaire used to examine the aggressive behavior of the participants. This instrument from Buss and Perry (1982) was also used as a pretest and posttest. Amini (2016) has adapted this instrument to the Indonesian culture. It consists of 29 items and has four subscales, namely: physical aggression, verbal aggression, anger, and hostility. A five-point Likert scale ranged from one to five $(1=$ "extremely uncharacteristic of me," $5=$ "extremely characteristic of me "), was used to 
respond to the questions. Each item was represented by one statement, for example, item number one: "my friends think I am angry" and item number 18: "I have difficulty controlling my emotions." The internal consistency of this subscale was measured with Cronbach's alpha and ranged from .72 to .85 . This scale was also found to have an excellent test-retest reliability, ranged from .72 to .80 (Buss \& Perry, 1992; Reyna et al., 2011; Iftikhar \& Malik, 2014; Valdivia-Peralta, FonsecaPedrero, Gonzalez-Bravo, \& LemosGiraldez, 2014; Clark, 2017). Validity and reliability were also measured, and the result showed a KMO value of .500 (sig. Barlett $=.044)$ and a Cronbach alpha value of .917 (CITC range = -.126-.971). The Aggression Questionnaire was given before and after the intervention, used a paper-based test, and conducted in the counseling room of the UPTD Kampung Anak Negeri.

\section{Procedure of intervention}

The anger management training was adapted from Simmonds's (2003) book entitled
Seeing Red: An Anger Management and Peacemaking Curriculum for Kids and Bhave and Saini's (2009) book entitled Anger Management. This training composed of nine sessions that addressed three aspects, namely cognitive, behavioral, and physiological components of anger. The cognitive aspect that would be targeted is the knowledge about aggression so that the participants understand better that aggressive behavior is less useful to bring up their anger. Besides, the training aims to increase the awareness about alternative methods to express anger without harming others and self. Behavioral aspects focus on explaining the alternative behavior, replacing the aggressive behavior, when the participant feel angry about something, without harming self and others. The physiological component of anger aims to increase physical sensitivity when anger arises. Therefore, before the anger arises, the participant can sense it, aware, realize, and know what to do for the next step for preventing aggression. The framework for anger management training modules is presented in Table 1.

Table 1.

The Module of Anger Management Training

\begin{tabular}{|c|c|c|}
\hline Session & Duration & Purposes \\
\hline $\begin{array}{l}\text { SESSION I: INTRODUCING } \\
\text { VARIOUS EMOTIONS }\end{array}$ & $10 \min$ & Participants are able to recognize different emotions \\
\hline \multirow{2}{*}{$\begin{array}{l}\text { SESSION II: INTRODUCING } \\
\text { ANGRY EMOTION }\end{array}$} & $5 \mathrm{~min}$ & $\begin{array}{l}\text { Participants have a better understanding about angry } \\
\text { emotion }\end{array}$ \\
\hline & $5 \mathrm{~min}$ & $\begin{array}{l}\text { Participants understand better about issues and matters, } \\
\text { that potentially make other people angry and participant } \\
\text { are able to express angry emotion. }\end{array}$ \\
\hline SESSION III: YES OR NO & $15 \mathrm{~min}$ & $\begin{array}{l}\text { Participant understand that angry could be triggered by } \\
\text { different causes. }\end{array}$ \\
\hline $\begin{array}{l}\text { SESSION IV: REASONS TO BE } \\
\text { ANGRY }\end{array}$ & $10 \mathrm{~min}$ & $\begin{array}{l}\text { Participants become more aware about the angry emotion } \\
\text { they felt. }\end{array}$ \\
\hline $\begin{array}{l}\text { SESSION V: WARNING: I'M } \\
\text { GETTING MAD }\end{array}$ & $20 \mathrm{~min}$ & $\begin{array}{l}\text { Participants are aware and have internal alert, when they } \\
\text { become lose control. }\end{array}$ \\
\hline SESI VI: WHEN I AM ANGRY, I... & $10 \mathrm{~min}$ & $\begin{array}{l}\text { Participants are aware of their behavior, when they are } \\
\text { angry. }\end{array}$ \\
\hline $\begin{array}{l}\text { SESSION VIII: EXPLANATION OF } \\
\text { AGGRESSIVE BEHAVIOR }\end{array}$ & $20 \mathrm{~min}$ & $\begin{array}{l}\text { Participants understand the definition and type of } \\
\text { aggressive behavior }\end{array}$ \\
\hline $\begin{array}{l}\text { SESI VII: TIME OF } \\
\text { RELAXATION! }\end{array}$ & $10 \mathrm{~min}$ & Participants learn to relax \\
\hline $\begin{array}{l}\text { SESI VIII: HOW TO MANAGE } \\
\text { OUR ANGER }\end{array}$ & $40 \mathrm{~min}$ & Participant learn to manage anger \\
\hline
\end{tabular}




\section{RESULTS AND DISCUSSION}

The participants were six male adolescences living in the UPTD of Kampung Anak
Negeri. Detailed information about the participant is described in Table 2.

Table 2.

Participant Description

\begin{tabular}{|c|c|c|c|c|c|c|}
\hline Information & Participant 1 & Participant 2 & Participant 3 & Participant 4 & Participant 5 & Participant 6 \\
\hline Name (initial) & $\mathrm{H}$ & B & $\mathrm{R}$ & D & AR & AT \\
\hline Age & 14 & 15 & 13 & 14 & 14 & 15 \\
\hline School grade & $5^{\text {th }}$ & $9^{\text {th }}$ & $6^{\text {th }}$ & $6^{\text {th }}$ & $5^{\text {th }}$ & - \\
\hline Background & $\begin{array}{l}\text { Street } \\
\text { children }\end{array}$ & $\begin{array}{l}\text { Neglected } \\
\text { child }\end{array}$ & $\begin{array}{l}\text { Neglected } \\
\text { child }\end{array}$ & $\begin{array}{l}\text { Neglected } \\
\text { child }\end{array}$ & $\begin{array}{l}\text { Neglected } \\
\text { child }\end{array}$ & $\begin{array}{l}\text { Neglected } \\
\text { child }\end{array}$ \\
\hline $\begin{array}{l}\text { CBCL score of } \\
\text { aggression }\end{array}$ & 27 & 24 & 22 & 29 & 20 & 36 \\
\hline
\end{tabular}

\section{Result of Data Analysis}

All participants attended complete nine sessions. According to the design, the intervention was held in two days. From the diagram 1 , it can be seen the comparison of scores between pre- and post-intervention.
The black bars describe the pretest scores, while the gray bars describe the posttest scores. In each subject, the gray bar is consistently higher than the black bar. Diagram 1 shows the increase in participants' knowledge scores about aggression after the intervention.

\section{Frequency Distribution of Knowledge}

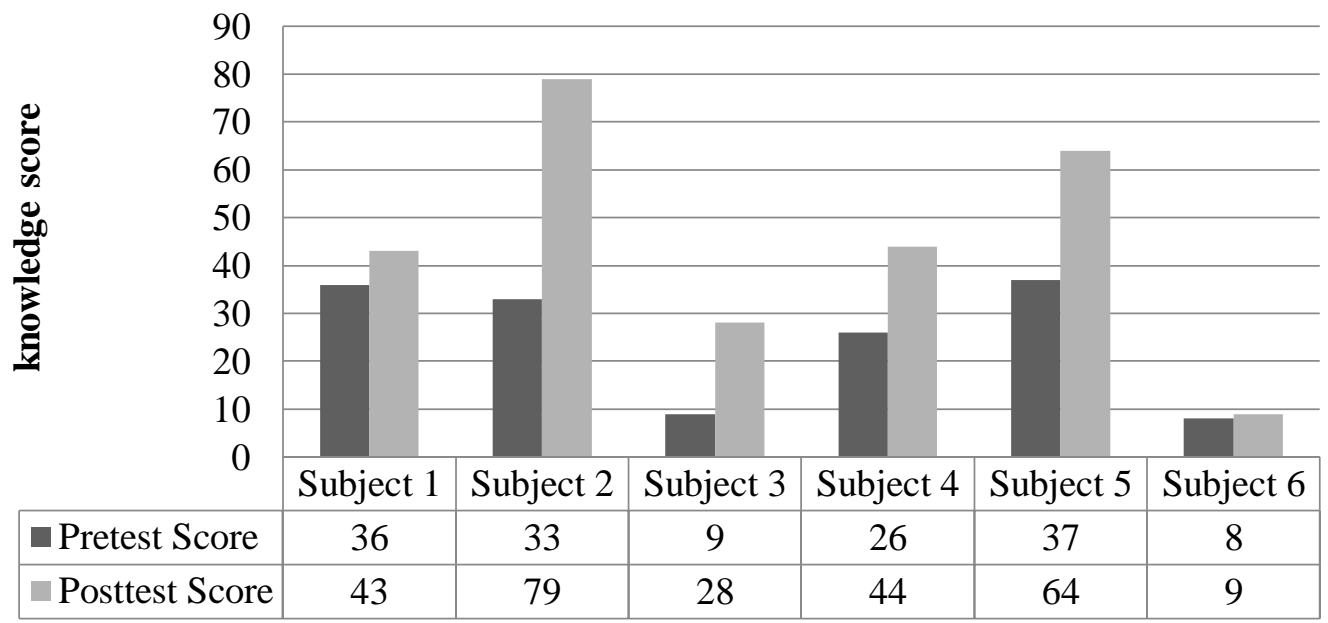

Figure 1. Frequency Distribution of Pretest and Posttest Score of Knowledge

According to diagram 1 , it can be regarded that participant scores of knowledge before and after intervention are the difference. The scores after the intervention are increasing. The wilcoxon signed-rank test shows a result of $\mathrm{Z}=-2.201(\mathrm{p}=.028)$ with a mean difference of -19.66 . This result confirms different scores of knowledge before and after the intervention, and it also explains the hypothesis. The average score of participants' knowledge after getting training $\left(\mathrm{M}_{\mathrm{k} 2}=44.50, \mathrm{SD}=24.921\right)$ is higher than before training $\left(\mathrm{M}_{\mathrm{k} 1}=24.83, \mathrm{SD}=13.227\right)$. It can be concluded that anger management training provides an effect on participants' knowledge about aggression, especially anger emotion, aggressive behavior, and methods to control the anger. Through this increased knowledge scores, it is expected that participants are also able to implement 
their knowledge in daily life and reduce angry. aggressive behavior when they are upset or

\section{Frequency Distribution of Aggression Behavior}

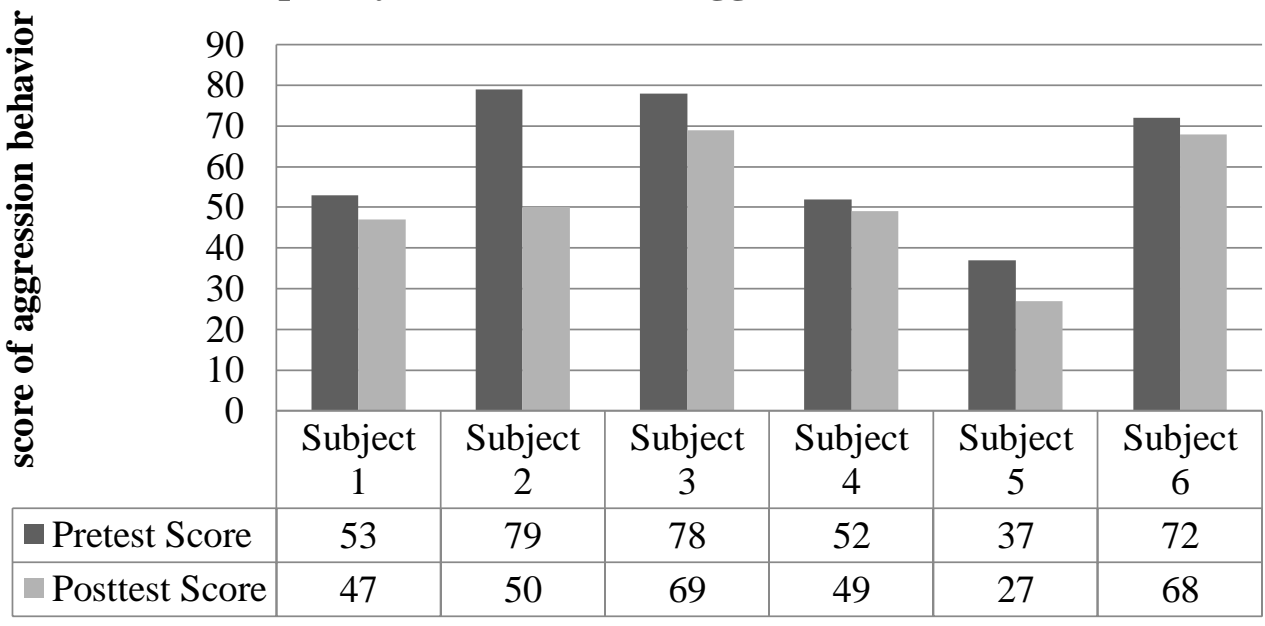

Figure 2. Frequency Distribution of Pretest dan Posttest score of Aggressive Behavior

Diagram 2 shows a decrease score of aggressive behavior in each participant after the training was conducted. The posttest was administrated one week after the training was conducted. The black bars show the participants' aggressive behavior scores before the intervention, while the gray bars show the aggressive behavior scores after the training. The gray bars are consistently lower than the black bars. It indicates that aggressive behavior scores are decreasing. The wilcoxon signed-rank test shows $\mathrm{Z}=-2.201(\mathrm{p}=.028)$. The result confirms a significant difference in aggressive behavior before and after the training. The average score before training is $\mathrm{M}_{\mathrm{b} 1}=61.833$ with standard deviation of $(\mathrm{SD})=17.034$, while after training is $\mathrm{M}_{\mathrm{b} 2}=51.666$ with standard deviation of $(\mathrm{SD})=15.539$. The score after training is lower than before training. So, it can be figured out that aggressive behavior diminishes after the training has been conducted. Anger management training affects reducing aggressive behavior. Through this training, it is also expected that participants are more able to control their emotions when they feel anger or upset.

Table 3.

The Effect Size of Aggressive Behavior Score

\begin{tabular}{cccccccc}
\hline \multicolumn{3}{c}{ Input parameter } & \multicolumn{5}{c}{ Output parameters } \\
\hline $\begin{array}{c}\text { Tails } \\
(\mathrm{s})\end{array}$ & $\begin{array}{c}\text { Effect } \\
\text { size d }\end{array}$ & $\begin{array}{c}\alpha \text { err } \\
\text { prob }\end{array}$ & $\begin{array}{c}\text { Total } \\
\text { sample } \\
\text { size }\end{array}$ & $\begin{array}{c}\text { Non cent. } \\
\text { Parameter }\end{array}$ & Critical t & Df & $\begin{array}{c}\text { Power (1- } \\
\beta \text { err prob) }\end{array}$ \\
\hline Two & .622 & .05 & 6 & 2.179 & 2.615 & 4.729 & .414 \\
\hline
\end{tabular}

Table 3 shows the number of effect sizes (d), which has a value of .622. It indicates that the effect resulted from the training is .622 and is a moderate effect. Moreover, the statistical power (1- $\beta$ err prob) is .414 , which can be explained that the anger management training has a power of $41.4 \%$ in rejecting the null hypothesis $\left(\mathrm{H}_{0}\right)$.

This study aims to determine the effect of anger management training on knowledge and aggressive behavior in adolescents living in UPTD Kampung Anak Negeri. The 
adolescent in UPTD Kampung Anak Negeri came from a similar background, such as neglected children, brat, and street children. Linares, Li, and Shrout (2012) find that neglected children show a poor understanding of negative emotions, lack empathy, and have poor coping strategies that increase the risk of aggressive behavior. The finding of Linares et al. could be the reason for the high aggressiveness score of CBCL in participants.

The result of the study is consistent with several previous studies. Mohammadi et al. (2010) conducted a study with 34 teenage students aged 12-15 years in Shabestar City. The results revealed that anger management training could reduce aggressive behavior and increase social adjustment in adolescents. Valizadeh, Davaji, and Nikamal (2010) conducted a study of 40 high school students with a mean age of 15 years. The results show that anger management training can reduce both aggressive behavior and idea (thought) of aggression in high school students. Mohammadiarya, Sarabi, Shirazi, Lachinani, Roustaei, Abbasi, and Ghasemzadeh (2012) conducted a study of 45 male junior high school students with a mean age of 13 years. The results of the study explained that anger management training was effective in reducing aggressive behavior in students. Other studies conducted by Mokhber, Masjedi, and Bakhtiari (2016) on adolescent girls aged 1518 years found that anger management training can significantly reduce aggressive behavior.

Mitrani (2010) declared that anger management training not only increases knowledge but also increase anger control or individual self-control when individuals feel angry. The anger management training program offers not only psychoeducation but also training and guiding to reduce the aggressive behavior, addressing in three aspects, namely cognitive, behavioral, and physiological components of anger (Bhave \& Saini, 2009). After the training was administrated, participants began to be aware of the reasons for feeling angry and understand internal signs or warnings when they were angry. Besides, participants also began to learn to manage their anger to minimize aggressive behavior that could harm both themselves and others. Participants also learn how to express their anger correctly, and others can better accept this expression of anger. The other alternatives to manage anger are relaxation, breathing with some technique, taking a little time to stay away from others, and expressing assertively without hurting others. The result of this study is also in line with the research of Mohammadi et al. (2010). Anger management training can also increase an individual's awareness in detecting anger feeling and increasing the skills to control anger effectively. Moreover, participants can also show appropriate and efficient reactions to stimuli from the environment.

The result of this study enriches the knowledge about reducing aggressive behavior in adolescents, which also means as the advantage of this study, because research focus on reducing aggressive behavior in adolescent is still lacking in the Child Welfare Institution (LKSA). The anger management training was smoothly and easily implemented, because the training design is very simple and the material is comprehendsible. Besides, the fascinating and diverse methods were applied in the training and it prevents the training from flatness. Worksheets used in this training provides a positive result. The availability of facilities and infrastructure, such as a large and conducive room for training, cooperative staff, were also important factors for a successful outcome. By means of appropriate room it enabled to easily observe and control the participant behaviors during the training. On the other hand, this study still has limitation. The absence of a control group brings up a question, whether the knowledge increase and aggressive behavior decrease are pure effect resulted from anger 
management training or could be caused by other outside training factors.

\section{CONCLUSION}

The result of this study shows that the anger management training gives effects to the knowledge about aggression and aggressive behavior in adolescent living in UPTD Kampung Anak Negeri. After anger management training was conducted, the participants' knowledge about aggression increased and the aggressive behavior decrease. The knowledge about aggression include different forms of emotions, positive and negative emotions, expression of emotion, and different kinds of aggressive behavior. The reduced in aggressive behaviors are characterized by awareness in angry feeling, understanding about inappropriate behavior in expressing the anger, and ability in implementing anger management in daily life. Participant are able to control their verbal and prefer to stay away from people, if they feel unable to control their anger.

\section{ACKNOWLEDGMENT}

We would like to take this opportunity to thank you for our mentor, Dr. Ide Bagus Siaputra and Dr. Rakhman Ardi, M. Psych. for the motivation in completing the publication and all staff of UPTD Kampung Anak Negri for the assistant and all facilitation during this research.

\section{REFERENCES}

Achenbach, T. M. (1991). Manual of the child behavior checklist/ 4-18 and 1991 profile. Burlington, VT: University of Vermont, Departement of Psychiatry.

Amini, N. K. (2016). Perbedaan tingkat agresivitas siswa MTS Sunan Kalijogo Malang berdasarkan jenis kelamin (Undergraduate's thesis, Universitas Islam Negeri Maulana
Malik Ibrahim, Malang). Retrieved from http://etheses.uinmalang.ac.id/3702/

Bhave, S. Y., \& Saini, S. (2009). Anger management. New Delhi: SAGE Publications, Inc.

Buss, A. H., \& Perry, M. (1992). The aggression questionnaire. Journal of Personality and Social Psychology, 63(3), 452-459. doi: 10.1037/00223514.63.3.452.

Clark, C. M. (2017). Validation of the young adult relational aggression scale (Doctoral dissertation). Retrieved from

https://aquila.usm.edu/cgi/viewconte nt.cgi $?$ article $=2453 \&$ context $=$ disserta tions

Eltink, E. M., Hoeve, J. T., De Jongh, T., Helm, G. H., Wissink, I. B., \& Stams, G. J. (2017). Stability and change of adolescents' aggressive behavior in residential youth care. Child \& Youth Care Forum, 47(2), 199217. doi:10.1007/s10566-017-9425$\mathrm{y}$.

Estévez, E., Jiménez, T. I., \& Moreno, D. (2018). Aggressive behavior in adolescence as a predictor of personal, family, and school adjustment problems. Psichothema, $30(1)$, 66-73. doi:10.7334/psicothema2016.294.

Foumany, G. H., \& Salehi, J. (2013). The effects of anger management skills training on aggression, social adjustment, and mental health of college students. Journal of Education and Management Studies, 3(4), 266-270.

Garcia-Sancho, E., Salguero, J. M., \& Fernandez-Berrocal, P. (2014). Relationship between emotional intelligence and aggression: A systematic review. Agression and 
Violent Behavior, 19, 584-591. doi:10.1016/j.avb.2014.07.007.

Glowacz, F., Véronneau, M.-H., Boët, S., \& Born, M. (2013). Finding the roots of adolescent aggressive behaviour. International Journal of Behavioral Development, 37(4), 319331. doi:10.1177/0165025413486418

Houbre, B., Tarquinio, C., Thuillier, I., \& Hergott, E. (2006). Bullying among students and its consequences on health. European Journal of Psychology of Education, 21(2), 183208. doi:10.1007/bf03173576.

Hsieh, I. J., \& Chen, Y. Y. (2017). Determinants of aggressive behavior: Interactive effects of emotional regulation and inhibitory control. PLOS ONE, 12(4), 19. doi:10.1371/journal.pone.0175651.

Iftikhar, R., \& Malik, F. (2014). Translation and validation of aggression questionnaire in a pakistani children cohort. Pakistan Journal of Social and Clinical Psychology, 12(1), 3945.

Jiménez, T. I., \& Estévez, E. (2017). School aggression in adolescence: Examining the role of individual, family and school variables. International Journal of Clinical and Health Psychology, 17(3), 251260. doi:10.1016/j.ijchp.2017.07.002.

Kampung Anak Negeri. (2018). Profil UPTD Kampung Anak Negeri. Surabaya: Diunduh dari Database Profil Kampung Anak Negeri.

Linares, L. O., Li, M., \& Shrout, P. E. (2012). Child training for physical aggression? Lesson from foster care. Children and Youth Services Review, 34(12), 2416-2422. doi:10.1016/j.childyouth.2012.08.010

Liu, J. (2004). Concept Analysis: Aggression. Issues in Mental Health Nursing, 25(7), 693714. doi:10.1080/0161284049048675 5.

Liu, J., Lewis, G., \& Evans, L. (2012). Understanding aggressive behaviour across the lifespan. Journal of Psychiatric and Mental Health Nursing, 20(2), 156168. doi:10.1111/j.13652850.2012.01902.x.

Lök, N., Bademli, K., \& Canbaz, M. (2018). The effects of anger management education on adolescents' manner of displaying anger and self-esteem: A randomized controlled trial. Archives of Psychiatric Nursing, 32(1), 75-81. doi:10.1016/j.apnu.2017.10.010.

López, E. E., Pérez, S. M., Ochoa, G. M., \& Ruiz, D. M. (2008). Adolescent aggression: Effects of gender and family and school environments. Journal of Adolescence, 31(4), 433450. doi:10.1016/j.adolescence. 2007. 09.007 .

Lozovska, J., \& Gudaite, G. (2013). The understanding of aggression motivation and the psychotherapy process. Social and Behavioral Sciences, 82, 360-365. doi:10.1016/j.sbspro.2013.06.275.Mit rani, A. T. (2010). Outcome of anger management training program in a sample of undergraduate students. Social and Behavioral Sciences, 5, 339-

344. doi:10.1016/j.sbspro.2010.07.10 1.

Mohammadi, A., Kahnamouei, S. B., Allahvirdiyan, K., \& Habibzadeh, S. (2010). The effect of anger management training on aggression and social adjustment of male 
students aged 12-15 of shabestar schools in 2008. Social and Behavioral Sciences, 5, 1690-1693. doi:10.1016/j.sbspro.2010.07.347.

Mohammadiarya, A., Sarabi, S. D., Shirazi, M., Lachinani, F., Roustaei, A., Abbasi, Z., \& Ghasemzadeh, A. (2012). The effect of training selfawareness and anger management on aggression level in iranian middle school students. Social and Behavioral Sciences, 46, 987-991. doi:10.1016/j.sbspro.2012.05.235.

Mokhber, T., Masjedi, A., \& Bakhtiari, M. (2016). The effectiveness of anger management training on decreasing the anger of unsupervised girl adolescents. Open Journal of Medical Psychology, 5, 66-71. doi:10.4236/ojmp.2016.54008

Nasir, R., \& Ghani, N. A. (2014). Behavioral and emotional effects of anger expression and anger management among adolescents. Social and Behavioral Sciences, 140, 565-569. doi:10.1016/j.sbspro.2014.04.471.

Neuman, W. P. (2014). Social research methods: Qualitative and quantitative approaches ( $7^{\text {th }}$ ed.). Harlow: Pearson Education Limited.

Pechorro, P., Barroso, R., Poiares, C., Oliveira, J. P., \& Torrealday, O. (2015). Validation of the Buss-Perry aggression questionnaire-Short form among portuguese juvenile delinquents. International Journal of Law and Psychiatry, 44, 75-80. doi:10.1016/j.ijlp.2015.08.033.

Poling, D. V., Smith, S. W., Taylor, G. G., \& Worth, M. R. (2019). Direct verbal aggression in school settings: A review of the literature. Agression and Violent Behavior, 46, 127-139. doi:10.1016/j.avb.2019.01.010.
Potirniche, N., \& Enache, R. G. (2014). Social perception of aggression by high school students. Social and Behavioral Sciences, 127, 464-468. doi:10.1016/j.sbspro.2014.03.291.

Rahayu, L. S. (2019, May 7). Rilis survei, Menteri Yohana: Mayoritas pelaku kekerasan anak teman sebaya. DetikNews. Rtrieved from https://news.detik.com/berita/d4539340/rilis-survei-menteri-yohanamayoritas-pelaku-kekerasan-anakteman-sebaya

Reis-Dennis, S. (2018). Anger: Scary good. Australasian Journal of Philosophy, $1-$

14. doi:10.1080/00048402.2018.1520 268.

Reyna, C., Lello, M. G., Sanchez, A., \& Brussino, S. (2011). The Buss-Perry Aggression Questionnaire: Construct validity and gender invariance among argentinean adolescents. International Journal of Psychological Research, 4(2), 30-37. doi:10.21500/20112084.775.

Rishel, C. W., Greeno, C., Marcus, S. C., Shear, M. K., \& Anderson, C. (2005). Use of the child behavior checklist as a diagnostic screening tool in community mental health. Research on Social Work Practice, 15(3), 195203. doi:10.1177/1049731504270382

Sandri, R. (2015). Perilaku bullying pada remaja panti asuhan ditinjau dari kelekatan dengan teman sebaya dan harga diri. Jurnal Psikologi Tabula Rasa, 10(1), 43-57.

Shokoohi-Yekta, M., Zamani, N., \& Ahmadi, A. (2011). Anger management training for mothers of mildly mentally retarded and slow learner children: Effects on motherchild relationship. Social and 
Behavioral Sciences, 15, 722726. doi:10.1016/j.sbspro.2011.03.17 2.

Simmonds, J. (2003). Seeing red: An anger management and peacemaking curriculum for kids. Minneapolis, MN: New Society Publishers.

Shokoohi-Yekta, M., Parand, A., \& Zamani, N. (2010). Anger management instruction for mothers: A cognitive behavioural approach. Social and Behavioral Sciences, 5, 13711375. doi:10.1016/j.sbspro.2010.07.2 90.

Sulaiman, M. R. (2019, 23 Juli). Anak Berhadapan Hukum Tertinggi, Potret Buram Perlindungan Anak Indonesia. Suara.com. Retrieved from https://www.suara.com/health/2019/0 7/23/071000/anak-berhadapandengan-hukum-potret-buramperlindungan-anak-diindonesia?page $=$ all

Valdivia-Peralta, M., Fonseca-Pedrero, E., Gonzalez-Bravo, L., \& Lemos-
Giraldez, S. (2014). Psychometric properties of the AQ aggression scale in Chilean students. Psicothema, 26(1), 39-46. doi:10.7334/psicothema2013.84.

Valizadeh, S., Davaji, R. B., \& Nikamal, M. (2010). The effectiveness of anger management skills training on reduction of aggression in adolescents. Social and Behavioral Scienes, 5, 1195-1199. doi:10.1016/j.sbspro.2010.07.260.

Wilkowski, B. M., \& Robinson, M. D. (2007). The cognitive basis of trait anger and reactive aggression: An integrative analysis. Personality and Social Psychology Review, 12(1), 321. doi:10.1177/1088868307309874.

Williams, R. (2017). Anger as a basic emotion and its role in personality building and pathological growth: The neuroscientific, developmental and clinical perspectives. Frontiers in Psychology, $8, \quad 1-$ 9. doi:10.3389/fpsyg.2017.01950. 